\title{
Application of Split Desktop Image Analysis and Kuz-Ram Empirical Model for Evaluation of Blast Fragmentation Efficiency in a Typical Granite Quarry*
}

\author{
${ }^{1}$ K. A. Idowu, ${ }^{2}$ B. M. Olaleye and ${ }^{2}$ M. A. Saliu \\ ${ }^{1}$ University of Jos, Nigeria \\ ${ }^{2}$ The Federal University of Technology, Akure, Nigeria
}

Idowu, K. A., Olaleye, B. M. and Saliu, M. A. (2021), “Application of Split Desktop Image Analysis and KuzRam Empirical Model for Evaluation of Blast Fragmentation Efficiency in a Typical Granite Quarry", Ghana Mining Journal, Vol. 21, No. 1, pp. 45-52.

\begin{abstract}
Evaluation of fragmentation efficiency is an integral aspect of blasting operation. This study therefore assesses the efficiency of fragmentation size at Eminent granite quarry, Ibadan, Nigeria using Split Desktop software and Kuz-Ram empirical model. Five muckpiles of blasted rocks with the same blast design were analysed. The muckpile images were captured using smart high precision digital camera and uploaded into computer for Split Desktop analysis. The results of the fragment size distribution obtained from Kuz-Ram vary slightly with that of the Split Desktop but follow similar trend. The average values of $\mathrm{F}_{80}$ and $\mathrm{F}_{90}$ from the Split Desktop image analysis were $90.96 \mathrm{~cm}$ and $98.24 \mathrm{~cm}$ respectively. The Kuz-Ram model values for $\mathrm{F}_{80}$ and $\mathrm{F}_{90}$ were $88.52 \mathrm{~cm}$ and $92.95 \mathrm{~cm}$ respectively. The results of the Split Desktop were compared to the results obtained from the Kuz-Ram experiential model. The findings showed that the results obtained from Kuz-Ram empirical model were in conformity with the results from the Split Desktop software based on empirical relationship. Hence, the model is good for preliminary evaluation of blast design.
\end{abstract}

Keywords: Blasting, Particle Size Distribution, Split Desktop Software, Muckpile, Fragmentation Indicator

\section{Introduction}

Blasting is carried out in mining to reduce the in-situ rocks to smaller size fragments that can be easily handled by loading and haulage equipment. The process involves breaking or loosening the rock to extract largest possible size at a reduced cost. To achieve this objective, quantitative and qualitative requirements of blast fragmentation are essential conditions that must be met (Singh et al., 2005 and Voulgarakis et al., 2016). Fragmentation degree plays important role in control and reduction of loading, transportation and crushing costs (Siddiqui et al., 2009; Akande and Lawal, 2013). Blasting could be seen as the first comminution process in quarrying and mining and thus, the size of fragments obtained should not exceed the gape of crusher for efficient operation (Shehu et al., 2020; Lawal 2020; Lawal et al., 2021). Elimination of extremely big fragments and minimisation of excessive fines in the muckpile are usually considered to essentially optimize blast fragmentation. Kuz-Ram model is commonly used to appraise blast design alternatives and minimise the number of trial blasts to ensuring required results (Strelec et al., 2011). According to Kuznetsov (1973), Kuz-Ram model is an empirical relationship that evaluates blast fragmentation by incorporating blast design parameters such as: blast geometry, explosive characteristics, quantity of explosive used and rock factor. It measures fragmentation by estimating the $50 \%$ passing size of a muckpile. From the two major methods of blast fragmentation assessment which are direct and indirect methods, each of the methods has its inherent issues. However, digital image analysis is a product of technological advancement and has become the most commonly used indirect method for evaluating the blast fragmentation (Bamford et al., 2017; Lawal, 2021 and Siddiqui et al., 2009). Statistical analyses were conducted in order to compare the results of the two techniques.

According to Badrud (2011), three basic phases are required for the determination of grain size distribution using image analysis method. These are: sampling site selection, imaging and image analysis. The sampling phase involves selection of sites to obtain samples that represent the blasted rock mass while high quality images which can be analysed are prepared at the imaging phase. The last phase determines the size distribution of fragments marked on the image and is measured after drawing the perimeter of fragments on the image. Research is constantly being conducted by mining researchers to improve the blast fragmentation using different models to predict fragmentation efficiency. Some researchers had recognised the link between the levels of accuracy, rapidity and optimality of the empirical models, image analyses and numerical models (Latham et al., 2003). Image analysis method includes: Split Desktop, WipFrag, FragScan, PowerSieve, GoldSize, BLASTFRAG, TUCIPS, IPACS, etc. (Dahlhielm, 1996; Havermann and Vogt, 1996; Maerz et al., 1996; Schleifer and Tessier, 1996; Raina et al., 2002, Sanchidrian et al., 2009; Siddiqui et al., 2009). Thus, the choice of a specific blast fragmentation method to be adopted depends on the needs that 
necessitated the analysis (Shehu et al., 2020; Lawal and Kwon, 2020). The image analysis technique is highly advantageous because it has no limitation on the size of samples that can be analysed and does not interrupt the production process. They are usually in the form of computer software or programs and highly affordable (Shehu et al., 2020; Lawal, 2021). However, the inherent errors of the method could be minimised by capturing a large number of highquality images for analysis. In this study, Split Desktop image analysis software is considered to study the rock fragmentation because of its advantages. It is a user-friendly software (Tavakol and Hosseini, 2017). The results of the software are more accurate and with lesser error.

\subsection{Description of the Study Area}

The study area is located at Oluyole Local Government, Ibadan, Oyo State, Nigeria. The quarry produces granite aggregates and it is in operation. Fig. 1 shows the Geological Map of Eminent quarry in Ibadan, Oyo State as extracted from the Geological Map of Nigeria, and Fig. 2 depicts the quarry site after the blasting operation. Eminent quarry is located geographically between the latitude $7^{0} 10^{\prime} 0$ " $\mathrm{N}$ to $7^{0} 20^{\prime} 0{ }^{\prime \prime} \mathrm{N}$ and longitude $3^{0}$ 50 ' 0" E to $4^{0} 00$ ' 0 " E at $159 \mathrm{~m}$ above the sea level.

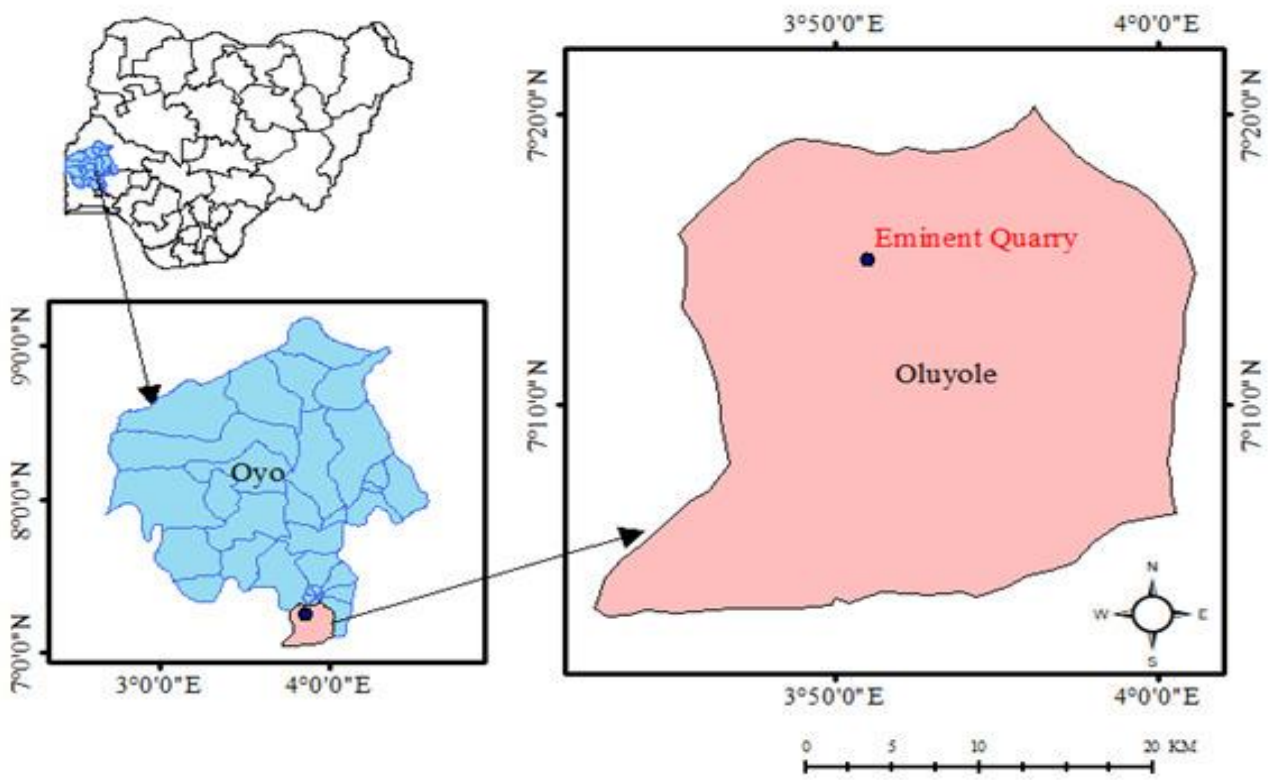

Fig. 1Map of Study Area

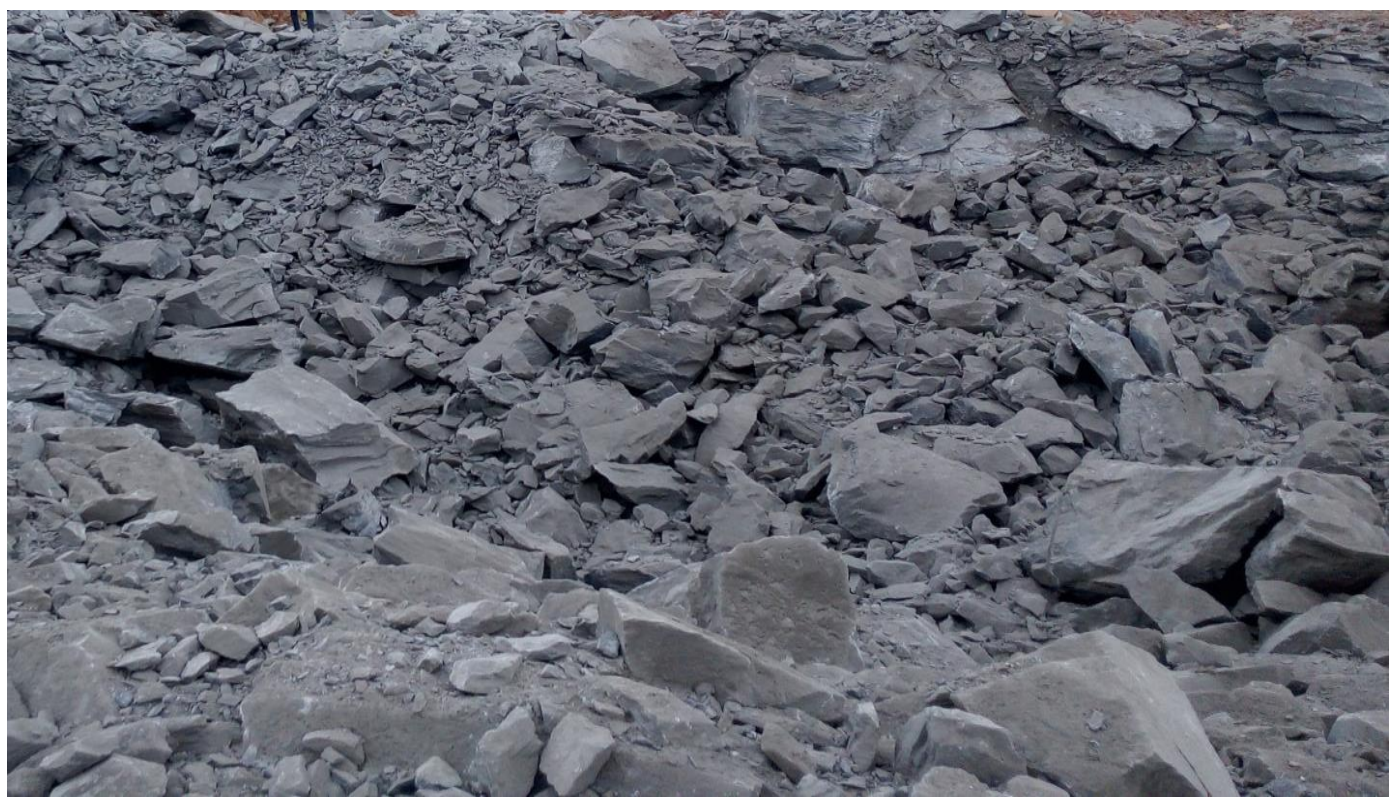

Fig. 2Eminent Quarry Site after Blasting 


\section{Resources and Methods Used}

In conducting this research, five blast operations at Eminent Quarry were studied and the resulting fragmentation was evaluated using the Split Desktop analysis and the Kuz-Ram empirical model. Split Desktop is designed for analysis of digital images retrieved from the digital camera and for determining the rock fragmentation gradation distribution. To capture accurate images, it is recommended that the horizontal axis of the camera should be at right angle to the surface of the blasted muckpile. In the field, deviation from this standard is utmost unavoidable. The images of muckpile at Eminent quarry were captured from the view point exactly in front of the muckpile with the horizontal axis of the camera at some varied angles from $90^{\circ}$ to the face of the muckpile. The images of muckpiles captured were thereafter uploaded into computer for the Split-Desktop analysis. Split Desktop analysis involves five phases for each image captured. In the first phase, the image is scaled. Secondly, it is dedicated to segmentation of rock fragments in each image. Thirdly, it gives permission for editing the desired rock fragments to ensuring precision of results. While the fourth phase involves the analysis of rock fragments marked in the image, and in the final stage, the fifth phase, the size distribution results are displayed in the form of diagrams (Bobo, 2010).

At Eminent quarry, the bench of the mine has height of $10 \mathrm{~m}$ with the same holes diameter of $76 \mathrm{~mm}$; while the sub-drill is assumed to be $1 \mathrm{~m}$. In the blast design, ANFO and emulsion type of explosives were used. The powder factor used is $0.25 \mathrm{~kg} / \mathrm{tons}$ and the delay between 2 consecutive detonators is 25 milliseconds.

According to Kuznetsov (1973), Kuz-Ram model is an empirical relationship that evaluates blast fragmentation by incorporating blast design parameters such as explosive characteristics, quantity of explosive used, blast geometry and rock factor. It measures fragmentation by estimating the $50 \%$ passing block size of a muckpile known as mean size $\left(\mathrm{X}_{50}\right)$. The two results from Split Desktop and Kuz-ram model were compared using statistical analyses. The Kuz-Ram model has three key equations; the Kuznetsovs Equation, RosinRammler Equation and the Uniformity index as shown in Equations 1- 3 (Shehu et al., 2020; Lawal 2021).

$$
X_{50}=A \times P f^{-0.8} \times Q^{\frac{1}{6}} \times\left[\frac{115}{R W S}\right]^{\frac{19}{30}}
$$

where $X_{50}$ is the mean particle size of muckpile $(\mathrm{cm})$, $A$ is the rock factor, $P_{f}$, is the powder factor $\left(\mathrm{kg} / \mathrm{m}^{3}\right)$, $Q$ is the mass of explosive in the blast hole $(\mathrm{kg})$ and
$R W S$ is the weight strength of explosive relative to ANFO.

According to Hustrulid (1999), the rock factor (A) of the model was selected to be 10 as shown in Table 1. The Rosin-Rammler distribution (Rosin and Rammler, 1933) was used to evaluate the proportion of muckpile passing through a specific screen size as given in Equation (2).

\section{Table 1Rock Factor Based on Structural Conditions}

\begin{tabular}{|l|l|}
\hline Rock mass condition & Rock factor A \\
\hline Very soft & 3 \\
\hline Soft & 5 \\
\hline Medium soft & 7 \\
\hline Rigid & 10 \\
\hline Rigid and homogeneous & 13 \\
\hline
\end{tabular}

(Source: Hustrulid, 1999)

$$
R(X)=1-e^{-\left(\frac{X}{X_{C}}\right)^{n}}
$$

where $R(X)$ is the \% passing through a screen opening of size $X, X$ is screen size $(\mathrm{cm}), X_{\mathrm{c}}$ is the characteristic size $(\mathrm{cm})$, and $n$ is the uniformity index.

According to Cunningham (1987), the uniformity index (n) was calculated by employing the effects of blast geometry as shown in Equation (3).

$$
n=\left[2.2-\frac{14 B}{d}\right]\left[\frac{1}{2}+\frac{S}{2 B}\right]^{0.5}\left[1-\frac{w}{B}\right] \times\left[\frac{L}{H}\right] P
$$

where $n$ is the uniformity index of the Kuz-Ram model; $B$ is burden (m); $S$ is spacing $(\mathrm{m}) ; d$ is the hole diameter $(\mathrm{mm}) ; w$ is the standard deviation of drilling precision $(\mathrm{m}) ; L$ is the charge length $(\mathrm{m}) ; H$ is the bench height $(\mathrm{m})$; and $P$ is the factor of staggered drilling pattern.

The uniformity exponent of the Rosin-Rammler distribution is estimated as a function of the blast design parameters. The characteristic size $\left(X_{c}\right)$ of the Rosin-Rammler distribution (Equation 2) was obtained using Equation (4).

$$
X_{c}=\frac{X_{50}}{(0.693)^{\frac{1}{n}}}
$$

\section{Results and Discussion}

A total number of five blasted muckpiles were analysed. The blast design parameters for the five blast operations are shown in Table 2 with the burden thickness of $2 \mathrm{~m}$ and spacing of blast holes of $2 \mathrm{~m}$. The particle size distribution analyses of the 
muckpile obtained from the five different blasts A to E using Split Desktop model are shown in Fig. 3. The maximum allowable size of the fragment that the primary crusher can handle is $100 \mathrm{~cm}$. The results of the Split Desktop processing of the blasted rock fragments are recorded in all the five blasts. The Split Desktop analyses show a very closely related particle size distribution for the five blasts with similar uniformity index of 1.7217 .

Table 2Blast Design Parameters

\begin{tabular}{|c|l|c|}
\hline S/N & \multicolumn{1}{|c|}{ Parameter } & Value \\
\hline 1 & Burden (m) & 2 \\
\hline 2 & Spacing (m) & 2 \\
\hline 3 & Bench height (m) & 10 \\
\hline 4 & Hole diameter (mm) & 76 \\
\hline 5 & Stemming (m) & 1 \\
\hline 6 & Sub-drill (m) & 0.4 \\
\hline 7 & Powder factor (kg/tons) & 0.25 \\
\hline 8 & $\begin{array}{l}\text { Quantity of Explosive } \\
\text { per meter }\end{array}$ & $\begin{array}{l}\text { ANFO }=3.75 \\
\text { kg }\end{array}$ \\
\hline 9 & $\begin{array}{l}\text { Explosive type } \\
\text { Ammonium } \\
\text { nitrate and } \\
\text { Bulk emulsion }\end{array}$ \\
\hline 10 & Delay time/interval & 25 ms \\
\hline
\end{tabular}

The $\%$ passing from the Split Desktop image analysis for the five blast operations are shown in Table 3, the average values of $F_{80}$ and $F_{90}$ are 90.96 $\mathrm{cm}$ and $98.24 \mathrm{~cm}$ respectively.

Table 3Values of \% passing obtained from Image Analysis of the five muckpiles

\begin{tabular}{|l|l|l|l|l|l|}
\hline Muckpile & A & B & C & D & E \\
\hline $\mathrm{F}_{5}$ & 13.8 & 18.6 & 14.8 & 17.6 & 19.2 \\
\hline $\mathrm{F}_{10}$ & 21.4 & 25.7 & 28.2 & 23.7 & 28.4 \\
\hline $\mathrm{F}_{20}$ & 36.9 & 39.2 & 34.8 & 40.2 & 39.7 \\
\hline $\mathrm{F}_{30}$ & 42.2 & 48.1 & 46.9 & 50.6 & 51.0 \\
\hline $\mathrm{F}_{40}$ & 53.5 & 59.3 & 61.3 & 66.4 & 62.8 \\
\hline $\mathrm{F}_{50}$ & 68.4 & 71.8 & 68.5 & 78.2 & 75.3 \\
\hline $\mathrm{F}_{60}$ & 78.9 & 80.3 & 74.9 & 83.6 & 84.6 \\
\hline $\mathrm{F}_{70}$ & 83.1 & 85.8 & 80.5 & 87.3 & 89.1 \\
\hline $\mathrm{F}_{80}$ & 89.8 & 90.1 & 86.7 & 94.8 & 93.4 \\
\hline $\mathrm{F}_{90}$ & 99.7 & 98.2 & 96.4 & 99.3 & 97.6 \\
\hline $\mathrm{F}_{100}$ & 100 & 100 & 100 & 100 & 100 \\
\hline
\end{tabular}

Fig. 4 shows the size distribution curve of the blast design obtained from the Kuz-Ram model while Figs. 5-9 compare the Kuz-Ram curve with the five results obtained from Split Desktop. The particle size distribution obtained from the Kuz-Ram model deviates from that of the Split Desktop model despite showing similar trend. The Kuz-Ram model shows that all the fragments of the muckpile are less than $100 \mathrm{~cm}$ benchmark.

Also, the five analyses from the Split Desktop indicate an allowable range of boulders. The five independent results from the Split desktop model are very close as shown in Fig. 10 and thereby reflecting the same design method. The small difference can be attributed to variation in rock mass structural features (Gheibie et al., 2009, Akbari et al., 2015). Table 4 shows the percentage passing obtained from the Kuz-Ram experiential model analyses of the blasted rock. The details of the percentage passing obtained from the Kuz-Ram experiential model and Split Desktop analyses of the blasted rocks are shown and compared in Table 5. The salient characterisation features of the analyses are also shown in Table 6.
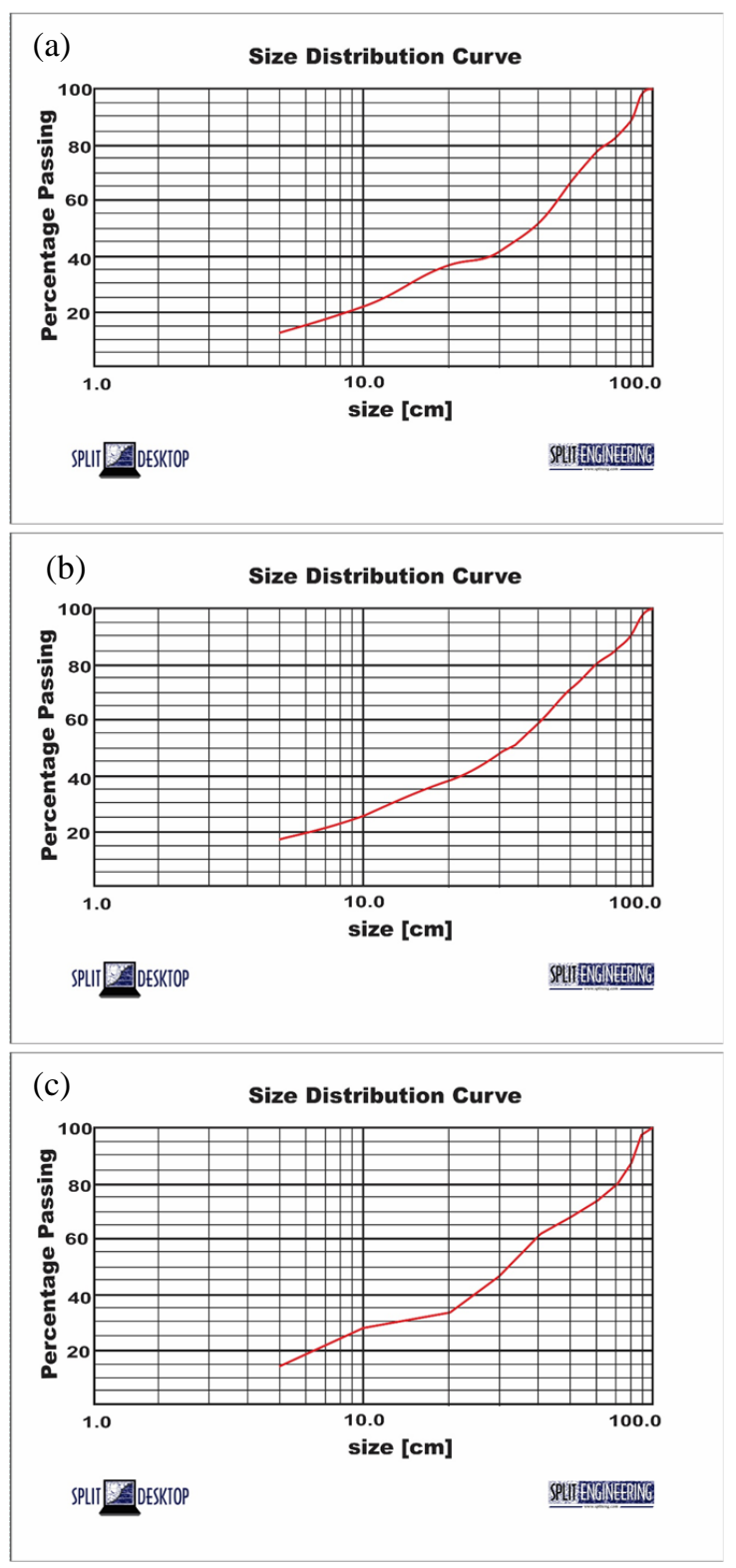

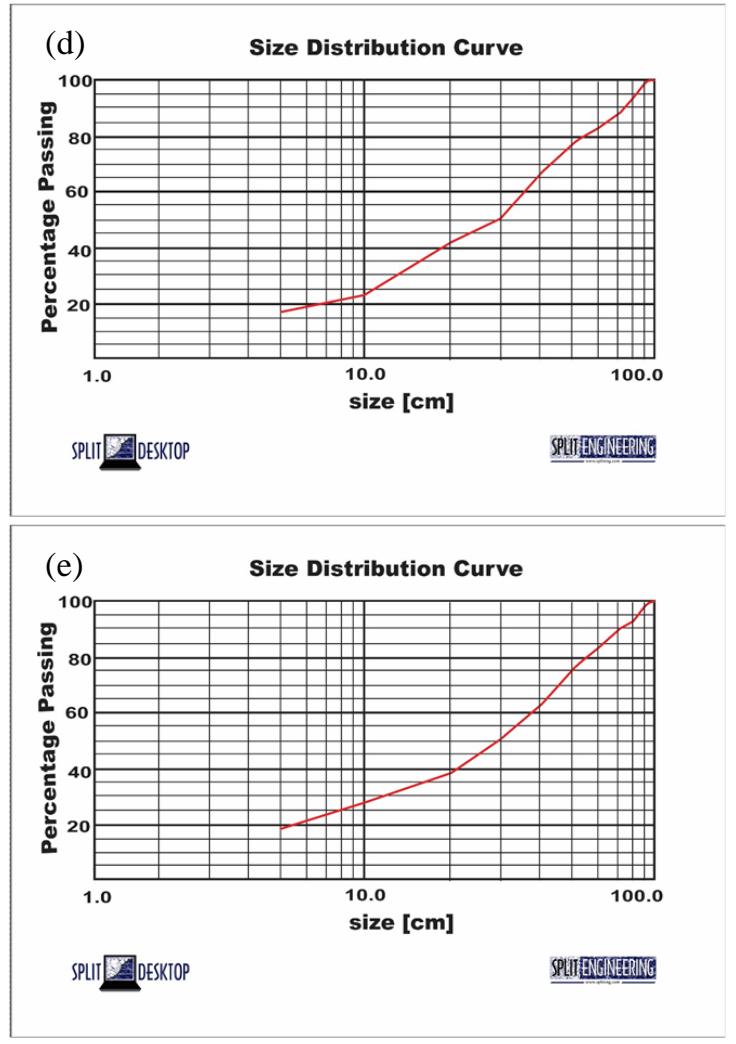

Fig. 3 Cumulative Grain Size Curves of Image Analysis of Blasts A- E

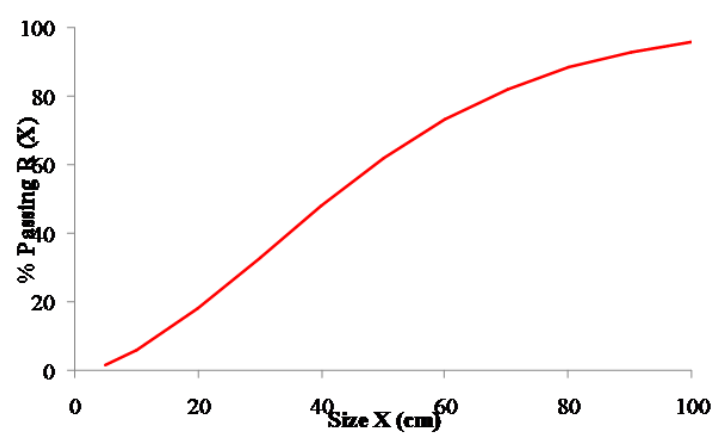

Fig. 4 Kuz-Ram Size Distribution Curve for Blast Design

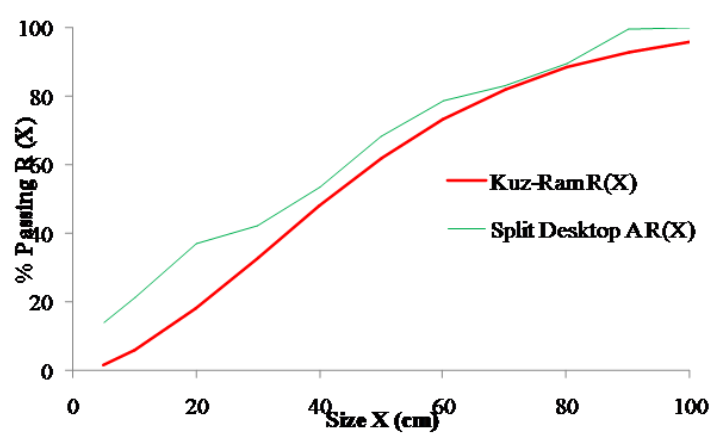

Fig. 5 Kuz-Ram versus Split Desktop Size Distribution Curves for Blast A

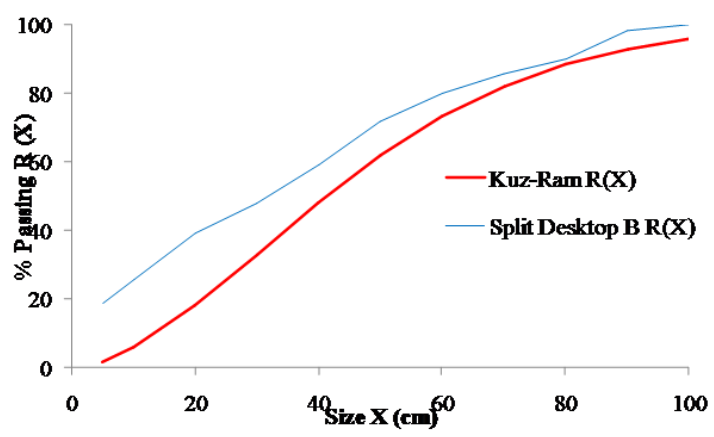

Fig. 6 Kuz-Ram versus Split Desktop Size Distribution Curves for Blast B

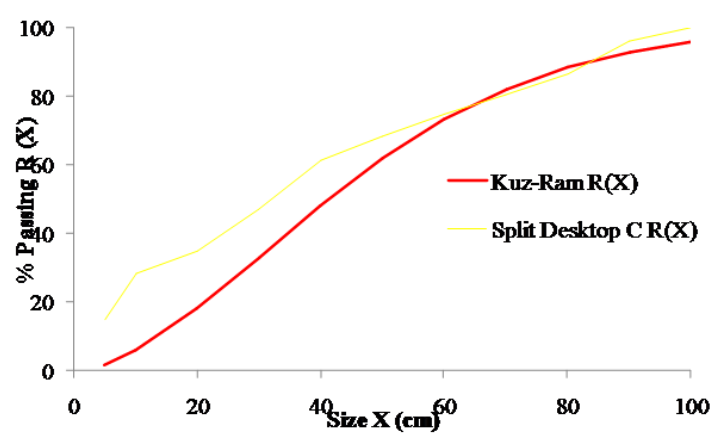

Fig. 7 Kuz-Ram versus Split Desktop Size Distribution Curves for Blast C

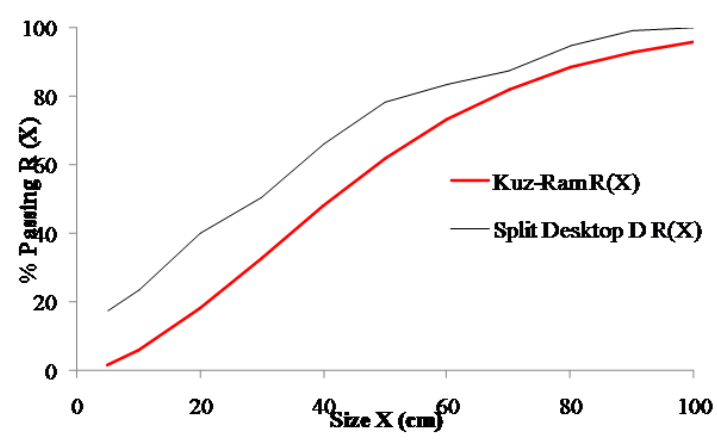

Fig. 8 Kuz-Ram versus Split Desktop Size Distribution Curves for Blast D

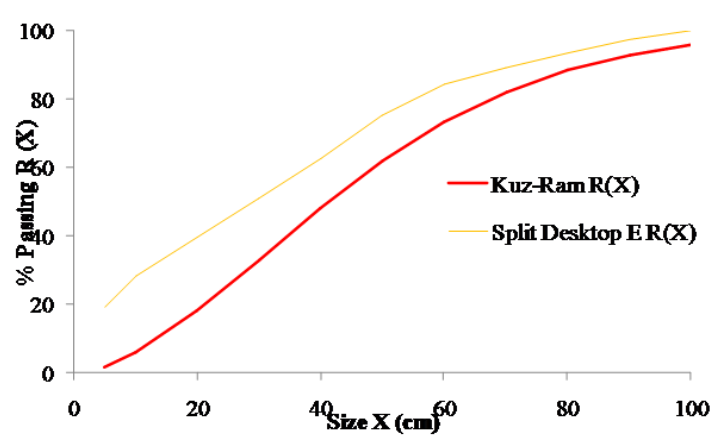

Fig. 9 Kuz-Ram versus Split Desktop Size Distribution Curves for Blast $\mathbf{E}$ 
Table 4 Results of the Kuz-Ram Experiential Model

\begin{tabular}{|c|c|c|c|c|c|c|c|c|c|c|c|}
\hline $\begin{array}{c}\text { Size } \\
(\mathbf{c m})\end{array}$ & $\mathbf{F}_{\mathbf{5}}$ & $\mathbf{F}_{\mathbf{1 0}}$ & $\mathbf{F}_{\mathbf{2 0}}$ & $\mathbf{F}_{\mathbf{3 0}}$ & $\mathbf{F}_{\mathbf{4 0}}$ & $\mathbf{F}_{\mathbf{5 0}}$ & $\mathbf{F}_{\mathbf{6 0}}$ & $\mathbf{F}_{\mathbf{7 0}}$ & $\mathbf{F}_{\mathbf{8 0}}$ & $\mathbf{F}_{\mathbf{9 0}}$ & $\mathbf{F}_{\mathbf{1 0 0}}$ \\
\hline $\begin{array}{c}\% \\
\text { Passing }\end{array}$ & 1.81 & 5.86 & 18.05 & 32.97 & 48.13 & 61.86 & 73.27 & 82.10 & 88.52 & 92.95 & 95.84 \\
\hline
\end{tabular}

Table 5 The Basic Percentage Passing for Kuz-Ram and Split Desktop Analyses of the Blasted Muckpiles

\begin{tabular}{|c|c|c|c|c|c|c|}
\hline $\begin{array}{c}\text { Size } \\
\mathbf{X}(\mathbf{c m})\end{array}$ & $\begin{array}{c}\text { Kuz-Ram } \\
(\boldsymbol{\%})\end{array}$ & $\begin{array}{c}\text { Split } \\
\text { Desktop } \\
\text { blast A (\%) }\end{array}$ & $\begin{array}{c}\text { Split } \\
\text { Desktop } \\
\text { blast B (\%) }\end{array}$ & $\begin{array}{c}\text { Split } \\
\text { Desktop } \\
\text { blast C (\%) }\end{array}$ & $\begin{array}{c}\text { Split } \\
\text { Desktop } \\
\text { blast D (\%) }\end{array}$ & $\begin{array}{c}\text { Split Desktop } \\
\text { blast E (\%) }\end{array}$ \\
\hline 100 & 95.84 & 100 & 100 & 100 & 100 & 100 \\
\hline 90 & 92.95 & 99.7 & 98.2 & 96.4 & 99.3 & 97.6 \\
\hline 80 & 88.52 & 89.8 & 90.1 & 86.7 & 94.8 & 93.4 \\
\hline 70 & 82.10 & 83.1 & 85.8 & 80.5 & 87.3 & 89.1 \\
\hline 60 & 73.27 & 78.9 & 80.3 & 74.9 & 83.6 & 84.6 \\
\hline 50 & 61.86 & 68.4 & 71.8 & 68.5 & 78.2 & 75.3 \\
\hline 40 & 48.13 & 53.5 & 59.3 & 61.3 & 66.4 & 62.8 \\
\hline 30 & 32.97 & 42.2 & 48.1 & 46.9 & 50.6 & 51.0 \\
\hline 20 & 18.05 & 36.9 & 39.2 & 34.8 & 40.2 & 39.7 \\
\hline 10 & 5.86 & 21.4 & 25.7 & 28.2 & 23.7 & 28.4 \\
\hline 5 & 1.81 & 13.8 & 18.6 & 14.8 & 17.6 & 19.2 \\
\hline
\end{tabular}

Table 6 Characterisation Features of the Analyses

\begin{tabular}{|l|c|c|c|}
\hline & $\begin{array}{c}\mathbf{X}_{\mathbf{5 0}} \\
(\mathbf{c m})\end{array}$ & $\begin{array}{c}\mathbf{X}_{\mathbf{c}} \\
(\mathbf{c m})\end{array}$ & $\mathbf{n}$ \\
\hline Kuz-Ram & 41.28 & 51.08 & 1.7217 \\
\hline $\begin{array}{l}\text { Split Desktop of } \\
\text { blast A }\end{array}$ & 39.5 & 48.87 & 1.7217 \\
\hline $\begin{array}{l}\text { Split Desktop of } \\
\text { blast B }\end{array}$ & 32.1 & 39.72 & 1.7217 \\
\hline $\begin{array}{l}\text { Split Desktop of } \\
\text { blast C }\end{array}$ & 32.7 & 40.46 & 1.7217 \\
\hline $\begin{array}{l}\text { Split Desktop of } \\
\text { blast D }\end{array}$ & 29.5 & 36.50 & 1.7217 \\
\hline $\begin{array}{l}\text { Split Desktop of } \\
\text { blast E }\end{array}$ & 29.8 & 36.87 & 1.7217 \\
\hline
\end{tabular}

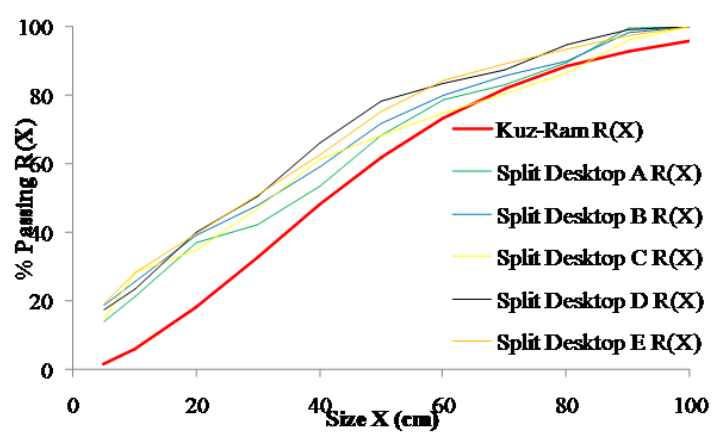

Fig. 10Kuz-Ram versus Split Desktop Size Distribution Curves for Blasts A, B, C, D and $\mathbf{E}$

The efficiency of fragmentation is given by the fragmentation indicator (FI) by comparing the produced fragments with the estimated ideal size obtained from the Kuz-Ram model (Shehu et al., 2020). If the FI value is less than 1, it implies that the average fragment size obtained is larger than the ideal size and when the FI value is greater than or equal to 1 , it shows a highly efficient fragmentation with average fragment size less than or equal to the ideal size. According to Shehu et al. (2020), fragmentation indicator (FI) for assessing the quality of blast fragmentation is as expressed in Equation (5).

$$
F I=\frac{X_{k r}}{X_{b m}}
$$

where $F I$ is fragmentation indicator, $X_{k r}$ is expected ideal mean size of the blasted material from KuzRam model $(\mathrm{cm})$ and $X_{b m}$ is mean size of blasted muck pile from particle distribution analysis $(\mathrm{cm})$.

Table 7 shows the fragmentation indication values for the five blasted muckpiles. The blast event values varied from 1.045 to 1.399 . From the principle of fragmentation indication, all the blast events A-E displayed very efficient fragmentation. However, the blast event D recorded the highest FI value of 1.399 and thereby considered as the most efficient fragmentation.

Table 7 Fragmentation Indicators for the Blasted Rock

\begin{tabular}{|c|c|c|c|c|}
\hline S/N & $\begin{array}{c}\text { Blast } \\
\text { Events }\end{array}$ & $\begin{array}{c}\mathbf{X k r} \\
(\mathbf{c m})\end{array}$ & $\begin{array}{c}\text { Xbm } \\
(\mathbf{c m})\end{array}$ & FI \\
\hline 1 & Blast A & 41.28 & 39.5 & 1.045 \\
\hline 2 & Blast B & 41.28 & 32.1 & 1.286 \\
\hline 3 & Blast C & 41.28 & 32.7 & 1.262 \\
\hline 4 & Blast D & 41.28 & 29.5 & 1.399 \\
\hline 5 & Blast E & 41.28 & 29.8 & 1.385 \\
\hline
\end{tabular}




\section{Conclusion}

This research was carried out to examine and compare particle size distribution of blast-induced fragmentation of Eminent granite quarry using the Kuz-Ram empirical model and the Split Desktop digital image analysis software. Five different blasts of similar blast design were analysed. From the analysis, the results of the Split Desktop show close relationship with one another. However, the minor differences could be attributed to human errors and structural geological features especially the discontinuity characteristics of the rock mass. Other factors that can cause the variations are the structural properties of rock mass such as the compressive strength, groundwater condition, joint aperture and joint infillings. The Split Desktop analyses how that different rock masses subjected to similar blast design will produce varied degrees of fragmentation as a result of inherent resistances of the rock mass during blasting. The average values of $F_{80}$ and $F_{90}$ obtained from the Split Desktop image analysis were $90.96 \mathrm{~cm}$ and $98.24 \mathrm{~cm}$ respectively. These average values of $\mathrm{F}_{80}$ and $\mathrm{F}_{90}$ percentage passing of the muckpiles are considered suitable for the quarry operation as a result of the values closeness to the allowable value of $100 \mathrm{~cm}$ of the crusher. The particle size distribution predicted from the KuzRam model shows significant variations from that of the Split Desktop and thus, do not reflect the true values obtained. The Kuz-Ram model underestimates the coarseness of the fragmentation and the mean fragment size predicted is smaller than the correct values in the five blast events studied. The results show that the model is very useful in the preliminary evaluation of blast design.

\section{Acknowledgement}

This research was supported and funded by the Federal Government of Nigeria through Tertiary Education Trust Fund (TetFund). The authors appreciate the management and Staff of Eminent Quarry, Ibadan, Nigeria for granting us access to their quarry. The authors are also grateful to the University of Jos, Nigeria and the Federal University of Technology, Akure, Nigeria for the use of their laboratories.

\section{References}

Akande, J.M. and Lawal A.I. (2013), “Optimization of Blasting Parameters Using Regression Models in Ratcon and NSCE Granite Quarries, Ibadan, Oyo State, Nigeria", Geomaterials, Vol. 3, No. 1, pp. 28-37.

Akbari, M.,Gholamreza, L., Alireza, Y. B. and Mohammad, G.(2015), "Blastability Evaluation for Rock Mass Fragmentation in Iran Central Iron Ore Mines", International Journal of
Mining Science and Technology, Vol. 25, No. 1, pp. 59-66.

Badrud, D. M. (2011), "Analysis of Gradation Methods for Blast Fragmentation Rocks", International Scientific Professional Quarterly of Mining Engineering, Vol. 30. Amirkabir University of Technology, Iran, pp. 32-35.

Bamford, T., Esmaeili, K. and Schoellig, A. P. (2017), "A Real-Time Analysis of Post-Blast Rock Fragmentation Using UAV Technology”, International Journal of Mining, Reclamation and Environment, Vol. 31, No. 6, pp. 439-456.

Bobo, T. (2010), "What's New with the Digital Image Analysis Software Split-Desktop", Split Engineering, LLC, Tucson, Arizona, USA.

Cunningham, C. V. B. (1987), "Fragmentation Estimations and the Kuz-Ram Model- Four Years On", In: $2^{\text {nd }}$ International Symposium on Rock Fragmentation by Blasting, Keystone, Colorado, Society for Experimental Mechanics, Bethel, pp. 475-487.

Dahlhielm, S. (1996), "Industrial Applications of Image Analysis - the IPACS System", In: J. A. Franklin and T. Katsabanis eds, Measurement of Blast Fragmentation, Montreal, Quebec, Canada, A. A. Balkema Publishers, Rotterdam, pp. 59-66.

Gheibie, S., Aghababaei, H., Hoseinie, S. H. and Pourrahimian, Y. (2009), "Modified Kuz-Ram Fragmentation Model and Its Use at the Sungun Copper Mine", International Journal of Rock Mechanics and Mining Sciences, Vol. 46, No. 6, pp. 967-973.

Havermann, T. and Vogt, W. (1996), “TUCIPS- A System for the Estimation of Fragmentation after Production Blasts", In: J. A. Franklin and T. Katsabanis, (eds.), Measurement of Blast Fragmentation, Montreal, Canada, A. A. Balkema Publishers, Rotterdam, pp. 67-72.

Hustrulid, W. A. (1999), "Blasting Principles for Open Pit Mining, General Design Concepts Theoretical Foundations", ISBN: 9054104597, A. A. Balkema Publishers, Rotter-dam, Vol. 1, pp. 201-213.

Kuznetsov, V. M. (1973), "The Mean Diameter of the Fragments Formed by Blasting Rock", Soviet Mining science, Vol. 9, No. 2, pp. 144-148.

Latham, J. P., Kemeny, J., Maerz, N. H., Noy, M., Schleifer, J. and Tose, S. (2003), "A Blind Comparison between Results of Four Image Analysis Systems Using A Photo-Library of Piles of Sieved Fragments", FragBlast, Vol. 7, No. 2, pp. 105-132.

Lawal, A. I. (2020), “An Artificial Neural NetworkBased Mathematical Model for the Prediction of Blast-Induced Ground Vibration in Granite Quarries in Ibadan, Oyo State, Nigeria", Scientific African, Vol. 8, p. 413.

Lawal, A. I. (2021), "A New Modification to the Kuz-Ram Model Using the Fragment Size 
Predicted by Image Analysis", International Journal of Rock Mechanics and Mining Sciences, p. 138.

Lawal, A. I., Kwon, S, and Kim, G. Y. (2021), "Prediction of the Blast-Induced Ground Vibration in Tunnel Blasting Using ANN, Metaheuristic ANNs and Gene Expression Programming”, Acta Geophysica, 69(1), pp.161174.

Lawal, A. I., Kwon, S. (2020), “Application of Artificial Intelligence in Rock Mechanics: An Overview", Journal of Rock Mechanics and Geotechnical Engineering, https://doi.org/10.1016/j.jrmge.2020.05.010.

Maerz, N. H., Palangio, T. C. and Franklin, J. A. (1996), "WipFrag Image Based Granulometry System", FRAGBLAST 5 Workshop on Measurement of Blast Fragmentation, pp. 91-99.

Raina, A. K., Choudhury, P. B., Ramulu, M., Chakraborty, A. K. and Misra, D. D. (2002), "FRAGALYST- An Indigenous Digital Image Analysis System for Grain Size Measurements in Mines", Journal of the Geological Society of India, Vol. 59, No. 6, pp. 561-569.

Rosin, P. and Rammler, E. (1933), "The Law Governing the Fineness of Powdered Coal", Journal of the Institute of Fuel, pp. 29-36.

Sanchidrian, J. A., Segarra, P., Ouchterlony, F. and Lopez, L. M. (2009), "The Accuracy of Fragment Size Measurement by Image Analysis in Combination with Some Distribution Functions", Journal of Rock Mechanics and Rock Engineering, Vol. 42, No. 1, pp. 95-116.

Schleifer, J. and Tessier, B. (1996), "FRAGSCAN: A Tool to Measure Fragmentation of Blasted Rock", In: J.A. Franklin and T. Katsabanis, (ed.s.), Measurement of Blast Fragmentation, Montreal, Canada: A. A. Balkema Publishers, pp. 73-78.

Shehu, S. A., Yusuf, K. O. and Hashim, M. H. M. (2020), "Comparative Study of WipFrag Image Analysis and Kuz-Ram Empirical Model in Granite Aggregate Quarry and their Application for Blast Fragmentation Rating", Journal of Geomechanics and Geoengineering, Taylor and Francis Group, pp. 1-10.

Siddiqui, F., Shah, S. and Behan, M. (2009), "Measurement of Size Distribution of Blasted Rock Using Digital Image Processing", Journal of King Abdulaziz University Engineering Sciences, Vol. 20, No. 2, pp. 81-93.

Singh, S. P., Narendrula, R. and Duffy, D. (2005), "Influence of Blasted Muck on the Performance of Loading Equipment", In: R. Holmberg et al., (eds.), 3rd EFEE World Conference on Explosives and Blasting, Brighton, United Kingdom, European Federation of Explosives Engineers, pp. 347-353.

Strelec, S., Gazdek, M. and Mesec, J. (2011), "Blasting Design for Obtaining Desired
Fragmentation", Technical Gazette, Vol. 18, No. 1, pp. 79-86.

Tavakol, E. A. and Hosseini, M. (2017), “Analysis of Blasted Rocks Fragmentation Using Digital Image Processing (Case Study: Limestone Quarry of Abyek Cement Company)", International Journal of Geo-Engineering, Springer, Vol, 8, No. 16, pp. 1-10.

Voulgarakis, A. G., Michalakopoulos, T. N. and Panagiotou, G. N. (2016), "The Minimum Response Time in Rock Blasting: A Dimensional Analysis of Full-Scale Experimental Data", Journal of Mining Technology, Vol. 125, No. 4, pp. 242-248.

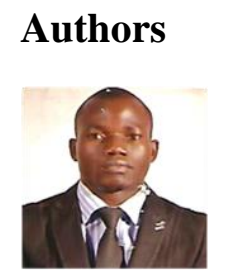

K. A. Idowu is a Lecturer in the Department of Mining Engineering, University of Jos, Nigeria and a PhD student at the Department of Mining Engineering of the Federal University of Technology, Akure (FUTA), Nigeria. He holds the degrees of B.Eng. and M. Eng in Mining Engineering from the Federal University of Technology, Akure, Nigeria. He is a Registered Engineer with Council for Regulation of Engineering in Nigeria (COREN) and a Member of the Nigerian Society of Engineers. He is also a Corporate Member of the Nigerian Society of Mining Engineers. His research and consultancy works cover Rock Mechanics, Drilling and Blasting; and Surface Mining.

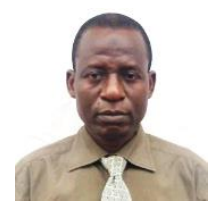

B. M. Olaleye is a Professor of Mining Engineering who is working at the Federal University of Technology, Akure, Nigeria. He holds the degrees of M. Eng. and PhD in Mining Engineering from the Federal University of Technology, Akure, Nigeria. $\mathrm{He}$ is a Registered Engineer with the Council for Regulation of Engineering in Nigeria (COREN) and Council of Nigerian Mining Engineers and Geoscientists (COMEG). He is also a Fellow of the Nigerian Society of Mining Engineers. His research and consultancy works cover Rock Mechanic and Rock Engineering; Rock Characterization and Rock Slope Stability Investigation.

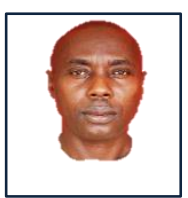

M. A. Saliu is a Professor of Mining Engineering and a Lecturer at the Federal University of Technology, Akure, Nigeria. He holds the degrees of B. Eng. and M. Eng. from the Federal University of Technology, Akure, Nigeria and $\mathrm{PhD}$ in Mining Engineering from the prestigious Camborne School of Mines, University of Exeter, United Kingdom. He is a Registered Engineer with the Council for Regulation of Engineering in Nigeria (COREN) and a Member of the Nigerian Society of Engineers. He is also a Corporate Member of the Nigerian Society of Mining Engineers. His research and consultancy works cover Rock Mechanics, Drilling and Blasting, Surface Mining and Blast Design. 